\title{
Dominant factors affecting uterine prolapse in Dr. Moewardi Hospital, Surakarta, in 20I3-20I5
}

\author{
Asih Anggraeni, Vitri Wulansari, Darto \\ Department of Obstetrics and Gynecology, Faculty of Medicine, \\ Sebelas Maret University, Dr Moewardi Hospital, Surakarta
}

\section{ABSTRAK}

Tujuan: Mengetahui faktor dominan yang mempengaruhi kasus prolaps uteri di Rumah Sakit Umum Daerah Dr. Moewardi Surakarta.

Bahan dan Metode: Penelitian ini dilakukan pada 258 kasus prolaps uteri di Rumah Sakit Umum Daerah Dr. Moewardi Surakarta periode Januari-Desember tahun 2013-2015. Penelitian ini merupakan studi analisis kuantitatif korelasional dengan teknik chi square dan analisis regresi.

Hasil: Faktor yang mempengaruhi prolaps uteri adalah paritas $(\mathrm{p}=0,024)$, usia $(\mathrm{p}=0,036)$ dan pekerjaan $(\mathrm{p}=0,039)$. Paritas merupakan nilai analisis regresi terbesar sebesar 0,145 dengan besar peluang terjadinya prolaps uteri pada paritas $>2$ dalam penelitian ini sebesar 2,753 kali bila dibandingkan dengan paritas s.

Simpulan: Faktor yang terbukti berpengaruh signifikan terhadap prolaps uteri yaitu umur, pekerjaan dan paritas. Paritas merupakan faktor yang paling dominan mempengaruhi prolaps uteri di Rumah Sakit Umum Daerah Dr. Moewardi Surakarta. (MOG 2017;25:77-80)

Kata kunci: Prolaps uteri; dominan; paritas; usia; pekerjaan

\begin{abstract}
Objectives: To determine the dominant factors that affected uterine prolapse at Dr. Moewardi General Hospital Surakarta. Materials and Methods: This study was conducted to 259 cases of uterine prolapse at Dr. Moewardi Hospital, Surakarta, in the periods of January - December in the years 2013-2015. This was a correlational quantitative analytic study using chi-square test and regression analysis.

Results: Factors affecting uterine prolapse were parity $(\mathrm{p}=0.024)$, age $(\mathrm{p}=0.036)$ and occupation $(\mathrm{p}=0.039)$. Parity had the highest regression analysis result of 0.145 with probability of uterine prolapse in those with parity $>2$ in this study was 2.753 times higher than in those with parity $\smile$.

Conclusion: Factors that had been proved to have significant effect on uterine prolapse were age, occupation, and parity. Parity was the predominant factor in affecting uterine prolapse in Dr. Moewardi Hospital, Surakarta. (MOG 2017;25:77-80)
\end{abstract}

Keywords: Uterine prolapse; dominant; parity; age; occupation

Correspondence: Asih Anggraeni, Department of Obstetrics and Gynecology, Faculty of Medicine, Sebelas Maret University, Dr Moewardi Hospital, Surakarta

\section{INTRODUCTION}

Pelvic organ prolapse is the descent of vaginal vault into the introitus followed by pelvic organ likes uterus, bladder, or rectum. ${ }^{1}$ The incidence of prolapse in various countries has increased, including the United States by $40 \%$, Australia $8 \%$, Sweden $31 \%$ and India $41 \%{ }^{2}$ The incidence of prolapse in Indonesia increased by 3.4$56.4 \%$ while the data at Cipto Mangunkusumo Hospital Jakarta showed that there are 47-67 cases every year. ${ }^{3}$ The number of uterine prolapse patients is increasing every year. Patients with uterine prolapse in this three years study were 258 cases, with an average of 86 cases each year. The number of uterine prolapse patients is increasing compared with the study in 2008 , which only had 21 cases.

Uterine prolapse caused by the damage of endopelvic fascia which are connective tissue, muscle of pelvic floor and inadequate supply of nerves.Genetic variants also cause this damage, caused by the changes in elastin gene expression in which elastin plays an important role in connective tissue and pelvic floor integrity. Besides, there are changes in type III collagen, which is the major collagen subtype in the vagina and its supporting structures. Type I collagen ratios versus type III is a tensile strength indicator of tissue. The higher the type III collagen, the lower tensile strength of the tissue got. Neurological damage is largely due to transvaginal reconstructive surgery and pervaaginam birth. The cause of prolapse during pregnancy is multifactorial, but hormones and enzymes are the main causes. Progesteron is known to reduce the strength of ureter, bladder, and urethra. Relaxin, a peptide hormone similar to insulin, is markedly increased during pregnancy and has a collagenolytic effect. The connective tissue of the rectus fascia and the obturator fascia may stretch during pregnancy, but in some wome these changes are reversible. $^{2}$

The etiology of prolapse is multi-factorial, such as pregnancy, vaginal delivery, menopause, estrogen deficiency, long-term intra-abdominal pressure increase (constipation, weight lifting, chronic obstructive pulmonary disease, straining), race, body mass index (BMI), genetic, anatomic, biochemical and metabolic factors of 
supporting tissue and surgical history. ${ }^{1}$ Factors that cause prolapse can be grouped into intrinsic and extrinsic factors. Intrinsic factors are collagen, genetics, age and ethnicity. Extrinsic factors are parity, hysterectomy, therapy, comorbidities and occupation in women who often carry heavy loads. ${ }^{4}$ Prolapses of the pelvic organs may also be affected by obesity.

Prolapses occur in half of women who have given birth, but only $5-20 \%$ is symptomatic. The prevalence of pelvic organ prolapses increased by $40 \%$ and every additional of 1 decade of a woman's age. Pelvic organ prolapses negatively affects the appearance and quality of life. ${ }^{1}$ Prolapses of pelvic organs do not cause mortality but increases morbidity, psychosexual and social burden. ${ }^{6}$ This study focused on age, parity, occupation, education, BMI (body mass index) and type of therapy performed, to determine the determinants of uterine prolapses at Dr. Moewardi Hospital.

\section{MATERIALS AND METHODS}

This study was a correlational quantitative analysis study on 258 cases of uterine prolapses at Dr. Moewardi Hospital Surakarta from January to December in 20132015. Sampling in this study was based on the medical record data. Exclusion criteria were bladder and rectum prolapse without accompanying uterine prolapse. Risk factor patterns included age, education, occupation, parity, BMI, and therapy. The data were presented descriptively to illustrate the dominant factors affecting uterine prolapses. Data were analyzed by chi square technique and regression analysis.

\section{RESULTS AND DISCUSSION}

Table 1. The description of uterine prolapse risk factor

\begin{tabular}{clcc}
\hline & Variables & Total & $(\%)$ \\
\hline \multirow{4}{*}{ Age } & $<30$ years old & 2 & 0.8 \\
& $31-40$ years old & 5 & 1.9 \\
& $41-50$ years old & 21 & 8.1 \\
& $51-60$ years old & 61 & 23.6 \\
& $61-70$ years old & 91 & 35.3 \\
& $>70$ years old & 78 & 30.2 \\
\hline \multirow{5}{*}{ Education } & Not in school yet & 14 & 5.4 \\
& Elementary & 188 & 72.9 \\
& Junior High School & 31 & 12.0 \\
& Senior High School & 21 & 8.1 \\
& Diploma & 1 & 0.4 \\
& Bachelor & 3 & 1.2 \\
\hline Occupation & Civil servant & 7 & 2.7 \\
& Private employees & 38 & 14.7 \\
& Farmer/Labor & 25 & 9.7 \\
& Housewives & 188 & 72.9 \\
\hline Parity & Parity $\leq 2$ & 49 & 19.0 \\
& Parity 3 - 4 & 99 & 38.4 \\
& Parity s $\geq 5$ & 110 & 42.6 \\
\hline
\end{tabular}

\begin{tabular}{clcc}
\hline BMI & $19-24$ & 242 & 93.8 \\
& $25-30$ & 16 & 6.2 \\
\hline Therapy & Hysterectomy & 75 & 29.1 \\
& Pessarium & 183 & 70.9 \\
\hline \multirow{2}{*}{ Uterine } & Grade I & 2 & 0.8 \\
Prolapse & Grade II & 65 & 25.2 \\
& Grade III & 127 & 49.2 \\
& Grade IV & 64 & 24.8
\end{tabular}

Based on Table 1, most of the respondents were in the 61-70 years old group, as many as 91 patients (35.3\%). Based on last education, most of the respondents were graduated from Elementary, as many as 188 patients $(72.9 \%)$. Based on the occupation, most of the respondents were housewives, as many as 188 patients (72.9 $\%)$. And from the analysis above, most of the respondents had parity than 5 times $(42.6 \%)$. Based on the BMI, most of the respondents had normal BMI with the score of $19-24$, as many as 242 patients $(98.8 \%)$. Based on the therapy, most of the respondents used pessarium, as many as 183 patients (70.9\%).

Table 2. Risk factors of uterine prolapse

\begin{tabular}{lcccc}
\hline & Chi Square & $\begin{array}{c}\text { P- } \\
\text { Value }\end{array}$ & OR & Description \\
\hline Age & 4.407 & 0.036 & 0.540 & $*$ \\
Education & 0.001 & 0.970 & 1.013 & Ns \\
Occupation & 4.257 & 0.039 & 2.106 & $*$ \\
Parity & 5.117 & 0.024 & 2.753 & $*$ \\
BMI & 0.612 & 0.434 & 1.284 & Ns \\
Therapy & 41.921 & 0.000 & 0.146 & $*$ \\
\hline
\end{tabular}

Notes:

Bivariate Analysis Results

$*$ = significant

Ns $=$ not significant

Based on the bivariate analysis results in Table 2, the factors that affect the prolapse are age, occupation, parity and therapy. The value of chi square of age as risk factor was 4.407 with $p$ value of $0.036(<0.05)$, occupation was 4.257 with $\mathrm{p}$ value of $0.039(<0.05)$, parity was 5.117 with $\mathrm{p}$ value of $0.024(<0.05)$, and therapy was 41.921 with $\mathrm{p}$ value of $0.000(<0.05)$. While the education and BMI factors did not give effect to uterine prolapse with $\mathrm{p}$ value above 0.05 .

Table 3. The dominant factors of uterine prolapse

\begin{tabular}{lcc}
\hline & Standardized beta & Rank \\
\hline Age & 0.050 & 6 \\
Education & 0.095 & 5 \\
Occupation & 0.143 & 2 \\
Parity & 0.145 & 1 \\
BMI & 0.104 & 3 \\
Therapy & 0.027 & 4 \\
Notes: Regression Analysis & &
\end{tabular}


Based on the regression analysis of uterine prolapse risk factors in Table 3, the most dominant factor that affect uterine prolapse was parity, as many as 0.145 . This study aimed to know the most dominant factor that affect uterine prolapse in outpatients and inpatients at Dr. Moewardi Hospital Surakarta in 2013-2015. The results showed that the most significant factors were age, occupation and parity.

Most of the subjects who had uterine prolapse in this study were women with parity more that 2 times, as many as 209 patients. Parity is a risk factor that increases the prolapse incidence. ${ }^{7}$ Result of this study showed that there was a significant effect between parity and uterine prolapse incidence while the effect was 0.145 . The result was consistent with previous study that showed significant association between parity and uterine prolapse incidence with the risk of multiparous women would experience uterine prolapse 3 times more than the non-multiparity women. ${ }^{8}$ In this study, there was one nulliparous subject. This is supported by the theory that prolapse can also occur in nulliparous women with weak pelvic muscle tissue. In this study, there were 2 respondents with young age who experienced prolapses after the first pregnancy. Previous studies had shown that prolapse is more common in women who had given birth than nulliparous women. ${ }^{9}$

In this study, it is dominated by unemployed women, as many as 188 women while women who work were 70 patients. Patients had low economy status with heavy domestic workloads. This was consistent with previous studies that showed that uterine prolapse incidence is higher in women with low economy status, job performed and workload experienced. ${ }^{10}$

In this study, the effect of BMI on prolapse was 0.104. BMI was not proven tho had a significant effect on uterine prolapse. The result of this study was not consistent with previous studies, that showed significant association between BMI and prolapse, while BMI score $\geq 30$ increases the risk of prolapse by $2.11 .^{11} \mathrm{In}$ this study, most respondents had normal BMI values.

The subjects of this research were mostly low educated, elementary graduated or not graduated were 202 patients, while respondents who had advanced education in junior high, senior high, diploma and bachelor were 56 patients. The result showed that the effect of education factor on uterine prolapse was 0.095. That factor was not proven to have significant effect on uterine prolapse.

This study was dominated by patients aged over 60 years, as many as 169 patients, whereas patients below 60 years old were 89 patients. This study showed that the age factor effect was 0.050. This factor was not proven tho had significant effect on the uterine prolapse. This study was dominated by respondents that chose pessary therapy, as many as 183 respondents, whereas the respondent that chose per vaginam hysterectomy was 75 patients. That was based on informed choice from the patients.

\section{CONCLUSION}

The factor proven to have significant effect on uterine prolapse were age, occupation, and parity, while parity was the most dominant factor of uterine prolapse in Dr. Moewardi Hospital in 2013-2015. In this study, the probability of uterine prolapse incidence in parity $>2$ was 2.754 times higher than parity $\mathcal{s}$.

\section{REFERENCES}

1. Junizaf and Budi. Panduan penatalaksanaan prolaps organ panggul. Konsensus Prolapse Organ Panggul HUGI POGI. Bali, November 7-9, 2013; p. 1-2.

2. Abrams P, Cardozo L, Khoury S, Wein. Incontinence. International Consultation on Incontinence. Paris, Juli 5-8, 2009; p.80-81, p.278-284.

3. Hardianti CB and Pramono AB. Faktor-faktor yang mempengaruhi prolap uteri di RSUP Dr. Kariadi Semarang. Media Medika Muda. 2015;4(4):496508.

4. Patel PD, Amrute KV, Gopal HB. Pelvic organ prolapse and stress urinary incontinence: A review of etiological factors. Indian Journal of Urology. 2007;23(2):135-141.

5. Tahir $M$ and Sabaratnam A. Obesity, a ticking time bomb for reproductive health. 1st edition. London, United Kingdom: Elsevier. 2013; p.563.

6. Adeoye IS, Ekwedigwe K, Daniyan B, et al. Pelvic organ prolapse: A significant cause of psychosexual and social burden. Sky Journal of Medicine and Medical Sciences. 2015; 3(6):67-70.

7. Doshani A, Teo RE, Mayne CJ, Tincello DG. Uterine Prolapse. BMJ: British Medical Journal. 2007;335:819-23.

8. Qomar F, Huma R, Muhammad K, Faiza A. Association of parity and pelvic organ prolapse. Journal of Rawalpindi Medical College Students Supplement. 2016;20(1):104-108.

9. Vita DD and Salvatore G. Two successful natural pregnancies in a patient with severe uterine prolapse: A case report. Journal of Medical Case Report. 2011;5:459.

10. Rajeev PB, Maithili B, Virender DS, Vivek A. Morbidity of uterine prolapsed among the women 
in the Chakrata block of Dehradun district. Indian Journal of Community Health. 2015;27:1.

11. Miedel A, Tegerstedt G, Schmidt M, Nyren O, Hammarstrom M. non obstetric risk factors for symptomatic pelvic organ prolapse. American College of Obstetricians and Gynecologist. 2009;113 (5):1089-97. 